Rev. Int. Contam. Ambie. 35 (1) 195-206, 2019

DOI: 10.20937/RICA.2019.35.01.14

\title{
LIFE CYCLE ASSESSMENT OF A TRADITIONAL BRICK MANUFACTURE IMPROVEMENT
}

\author{
Héctor Alfredo LÓPEZ-AGUILAR ${ }^{1}$, Enrique Alberto HUERTA-REYNOSO ${ }^{1}$, Jorge Alberto GÓMEZ ${ }^{2}$, \\ José Alberto DUARTE-MOLLER ${ }^{1}$ and Antonino PÉREZ-HERNÁNDEZ ${ }^{1 *}$
}

${ }^{1}$ Departamento de Metalurgia e Integridad Estructural, Centro de Investigación en Materiales Avanzados, Miguel de Cervantes 120, Complejo Industrial Chihuahua, 31136 Chihuahua, Chih., México

${ }^{2}$ Universidad Autónoma de Ciudad Juárez, Av. del Charro 450, Col. Partido Romero, 32310 Ciudad Juárez, Chihuahua, México

*Corresponding author; email: antonino.perez@cimav.edu.mx

(Received September 2017; accepted May 2018)

Key words: environmental impact, LCA, sustainable process

\begin{abstract}
This research studies the application of a life cycle assessment (LCA) methodology to evaluate the environmental impacts of an improvement to traditional brick manufacture. This study case was carried out using realistic combustion gas measurements and experimental results. The traditional process and the addition of one or two hopper blower (HB) devices provided the three scenarios for this study, which were evaluated quantitatively using a set of metric indicators for potential impacts while applying a "cradle-to-gate" approach. A decreasing trend was observed for most values of the potential impact categories when the device was used. An opportunity to improve the traditional process by adding this device has been identified, as a reduction in the environmental impact categories has been observed. The study suggests that the LCA tool may be valuable for quantifying the environmental impacts of improvements in the processes.
\end{abstract}

Palabras clave: impacto ambiental, acv, procesos sostenibles

\section{RESUMEN}

Se estudia la aplicación de la metodología análisis de ciclo de vida (ACV) para evaluar los impactos ambientales de una mejora en la manufactura tradicional de ladrillo. El caso de estudio se desarrolló utilizando mediciones de gases de combustión in situ y resultados experimentales. Se analizaron tres escenarios: proceso tradicional y utilización de uno o dos dispositivos (tolva-soplador), los cuales fueron evaluados cuantitativamente. Para ello se utilizó un conjunto de indicadores métricos de impactos potenciales mediante una aproximación "de la cuna a la puerta". Se identificó una oportunidad de mejorar el proceso tradicional al implementar el dispositivo, ya que se observó una reducción en el impacto ambiental en cada categoría. El estudio sugiere que la metodología ACV es una valiosa herramienta para cuantificar los impactos ambientales de mejoras en los procesos. 


\section{INTRODUCTION}

Recently, several countries have committed to international agreements to reduce greenhouse gases (GHG) emissions. Therefore, it is necessary to carry out an evaluation of the most polluting processes. The brick kiln industry represents one of the major smallscale industries which fulfill the growing demand for urban expansion. This industry generates negative impacts on the environment in respect of air quality, human health and vegetation in particular (Skinder et al. 2014). Ceramic bricks are one of the most impacting materials in the whole building process (Martínez-Rocamora et al. 2016), even though this appears to be a very profitable business (Singh and Asgher 2005). China tops global production and its manufacturing process is increasingly dominated by modern technologies (Schmidt 2013). About 250 billion bricks are produced in the Indian industry, which is the world's second largest-brick producer overall and the largest artisanal producer (Rajarathnam et al. 2014). Nevertheless, the producers of Latin America tend to rely on the most primitive and most polluting types of kilns (Schmidt 2013). There are more than 17000 artisan bricklayers in Mexico according to the Instituto Nacional de Ecología y Cambio Climático (National Institute of Ecology and Climate Change (INECC 2013).

The brick kilns may be grouped into two broad categories known as intermittent and continuous kilns. Most of the kilns around the world that contribute to the pollution of environments are traditional intermittent (Rajarathnam et al. 2014). It seems therefore fundamental to asses and quantify the environmental impact of this production process (Hoxha et al. 2016).

Life cycle assessment (LCA) is a methodological tool used in industry to evaluate the environmental impacts of products, and improve operation and manufacturing efficiency (Güereca et al. 2015). Actually, the most frequently addressed topics are waste management, construction, agriculture, transport, and chemical sector, among others (Bovea et al. 2017). Some international LCA studies have been conducted to analyze the environmental impacts of buildings (Bribián et al. 2009, Saner et al. 2013, Zhang et al. 2013, Hoxha et al. 2016) and construction materials (Buyle et al. 2013, Castell et al. 2013, Ibbotson and Kara 2013, Lasvaux et al. 2015). Recently, it has been found that construction materials can be responsible for $20-90 \%$ of the global warming potential (GWP) indicator and the variation is mainly due to the building projects and the embodied energy of the materials employed (Hoxha et al. 2016). However, information available on the life-cycle impacts of the traditional brick manufacturing process is limited. The aim of this work is to quantify the environmental impacts of Mexican brick manufacturing scenarios, evaluating an improvement in performance.

\section{MATERIALS AND METHODS}

\section{Life cycle assessment (LCA)}

An LCA quantifies the potential environmental impact of a product or a service throughout its lifecycle (ISO 2006a). Its main advantages are its elaborate framework for data collection and quantification of environmental exchanges between the system of interest and the environment. The LCA methodology can evaluate opportunities for environmental improvements (Nouri et al. 2012). The International Organization for Standardization has regulated the LCA framework, which consists of four elements: (a) goal and scope definition, (b) inventory analysis (c) impact assessment, and (d) interpretation. The traditional Mexican brick manufacturing process was selected as a case study and the international standards were analyzed (ISO 2006a, b).

\section{LCA goal and scope definition}

The objective of this LCA study was to evaluate the environmental impacts of three fired-brick processes under the following conditions:

Scenario I. Traditional intermittent brick manufacturing process in the clamp kiln (Fig. 1a).

Scenario II. Traditional process adding a hopperblower (HB) device (Fig. 1b). This device is used to increase the quantity of air blown while mixing it with fuel inside the clamp kiln.

Scenario III. Traditional process adding two HB devices.

The scope of this LCA study covers the stages of raw material extraction, transport to the production floor and production process. This last stage involves preparing mixtures, molding, drying and firing. Figure 2 depicts the system boundaries for the study. The emissions related to the energy embodied in machinery and buildings, as well as the personal transport of the workers were excluded. The "cradleto-gate" approach deducts the transport of the final product to its point of sale.

The functional unit of this study is the production of one traditional clay fired-brick in standard size (7, 14 , and $28 \mathrm{~cm}$ ) manufactured with $1.29 \mathrm{~kg}$ of clay and $200 \mathrm{~mL}$ of water, under the operating conditions 


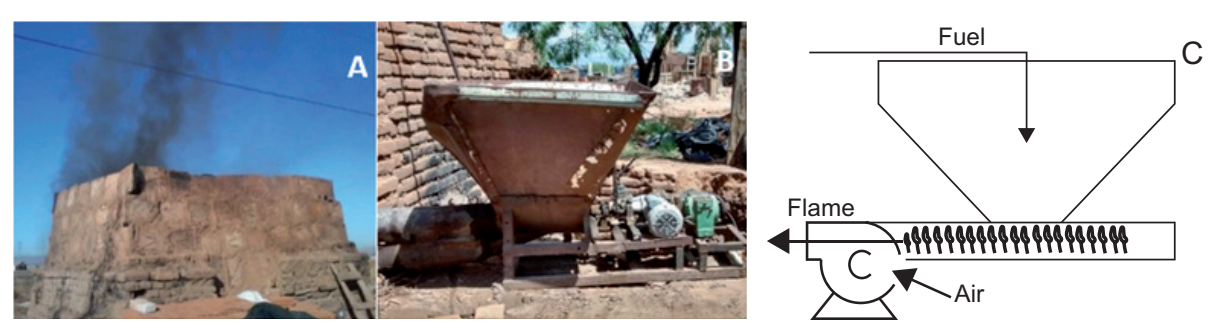

Fig. 1. (a) Traditional clamp kiln, (b) hopper-blower device picture, (c) flow diagram of hopperblower device

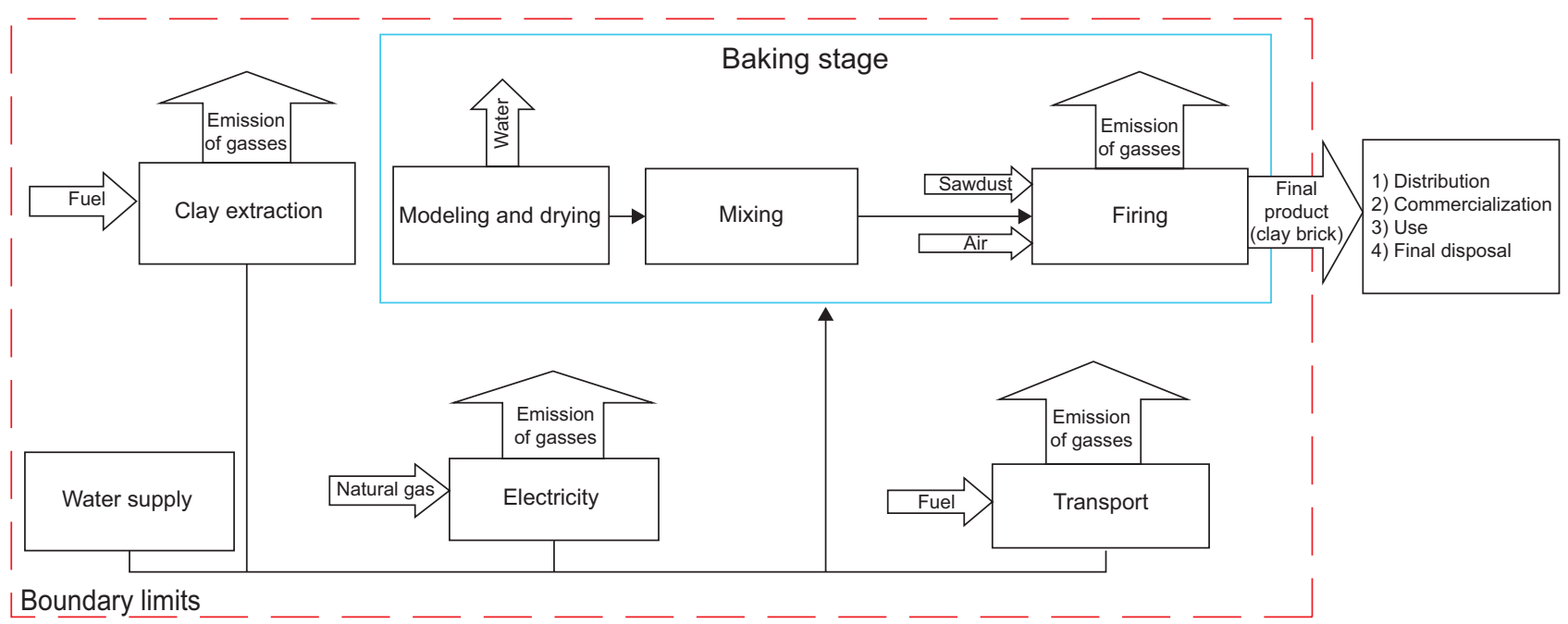

Fig. 2. System boundary of life cycle assessment of traditional Mexican brick manufacture

of the traditional clamp kiln with a 17000 bricks capacity (average work temperature, $900{ }^{\circ} \mathrm{C}$ ).

\section{Inventory database and life cycle impact assess- ment (LCIA) methods}

The inventory analysis collects input and output data to perform a quantitative description of all the material and energy flows across the system boundary. The quantity and quality of data may have a significant impact on the final results (Zhang et al. 2013). The majority of the data for the consumption of fuel and raw materials was collected experimentally in collaboration with local producers. The $\mathrm{CO}_{2}$, $\mathrm{CO}$, and $\mathrm{O}_{2}$ emission concentrations were determined with a gas analyzer (Testo 330-LI with $0.2 \mathrm{~L} / \mathrm{min}$ ) at the combustion kiln outlet. Residual sawdust is widely used as fuel by the brickmakers. In order to measure the concentration of sawdust elements, C, $\mathrm{H}, \mathrm{N}$ and $\mathrm{S}$ were analyzed using a gas chromatograph (EA110, CE Instruments). The chlorine concentration was measured using argentometric analysis.

Mass balance based on fuel characterization was realized to predict the average concentrations of the combustion gas mixture output. In order to calculate the air emissions inventory, the following assumptions were made: (i) the study considered that only $\mathrm{N}$ contained in fuel reacts to produce $\mathrm{NO}_{\mathrm{x}}$ emissions, represented as equivalent nitrogen monoxide, (ii) polychlorinated compounds were represented as equivalent 2,3,7,8-tetrachlorodibenzo-p-dioxin, (iii) the generation of polychlorinated compounds were calculated according to chlorine concentrations in sawdust, with the worst-case scenarios being where all the chlorine generates polychlorinated compounds, and (iv) particulate matter emissions were excluded due to non-homogeneous fire conditions measures, even though particulates are highly significant in brick manufacture.

The life cycle inventory (LCI) data for clay extraction and the environmental impact of transport was calculated using the AP-42 emission factors of the Environmental Protection Agency for non-controlled diesel motors (EPA 1995). All the transport distances were measured by a PC serial port (RS232) GPS system. The considered distances were: (i) $14.6 \mathrm{~km}$ between the extraction zone and the brick production 
zone, (ii) $9.36 \mathrm{~km}$ between the water supply zone and the brick production zone, and (iii) $14.65 \mathrm{~km}$ between the sawdust production zone and the production zone.

The electricity generation inventory was carried out and the emissions were also calculated according to emission factors AP-42 for natural gas combustion (EPA 2009). The process information was supplied by the combined cycle power plant El Encino (Chihuahua Mexico), which operates using natural gas combustion and has less environmental impacts compared to coal combustion systems (Agrawal et al. 2014).

There are two main categories of LCA databases: the generic database mainly provided by academics and databases provided by the specific industry (Lasvaux et al. 2015). The ecoinvent and $\mathrm{GaBi}$ databases were identified as the most complete LCA databases for assessment construction materials (MartínezRocamora et al. 2016). The present study was carried out using the LCA software SimaPro 7.3, ecoinvent v. 2.2 database parameters, and in situ measurements. In order to prove the sensibility of the characterization from different perspectives, three different LCIA methods were selected to translate the inventory data into impact categories:

- Eco-indicator 99. This method was developed by PRé Consultants with a damage-oriented approach. It has three different approaches, namely egalitarian, hierarchist, and individualist. The egalitarian and individualist approaches are focused more on the radical reality than the hierarchist. This study used the egalitarian perspective of Eco-indicator 99.

- Impact 2002+. It was developed by the Swiss Federal Institute of Technology-Lausanne, and it is a combined midpoint, endpoint and damage approach. It provides the distinction between impact and damage categories. This study was carried out using the midpoint approach.

- CML 2001. This was proposed by the Leiden University Institute of Environmental Science and is primarily a midpoint approach.
- ReCiPe. This method is a joint project effort between PRé Consultants and the Leiden University Institute of Environmental Science. The ReCiPe project is an integrated approach that combines the midpoint approach of CML 2001 with the damage approach of Eco-indicator 99 (Bare and Gloria 2006, Quirós et al. 2015). The ReCiPe method works with two levels of indicators: midpoint and endpoint. The midpoint approach was selected for this study.

Although midpoint indicators are relatively more difficult to interpret in comparison to endpoint indicators, their uncertainty is lower than in the latter (Cappuyns and Kessen 2012). Midpoint methodologies have a more comprehensive coverage of inventory flows than damage methodologies (Bare and Gloria 2006). Furthermore, the guidelines recommend more comprehensive coverage of impacts, more scientifically based modeling and more international consensus within these models, and these are all addressed within midpoint models.

\section{RESULTS AND DISCUSSION}

\section{Life cycle inventory (LCI) analysis}

The measurements of gas concentrations (Table I) suggest that firing time and GHG emissions will reduce if the amount of air in the combustion system is increased. Elemental chemical analysis of sawdust showed a weight content of $47.92 \%$ carbon, $3.47 \%$ nitrogen and $0.03 \%$ chlorine; sulfur was not detected, hence $\mathrm{SO}_{\mathrm{x}}$ emissions were not considered in the mass balance. The identified chlorine could be attributed to pentachlorophenol, a commonly used wood preserving agent. The presence of polychlorinated compounds (furans and dioxins) is highly likely in manufactured pentachlorophenol (Tondeur et al. 2010); thus, the combustion of the used fuel (waste sawdust) could generate these compounds

TABLE I. MEASUREMENTS OF AVERAGE GAS CONCENTRATIONS

\begin{tabular}{lcccccc}
\hline Gas & $\begin{array}{c}\text { Scenario I } \\
\%\end{array}$ & $\begin{array}{c}\text { SD* } \\
\%\end{array}$ & $\begin{array}{c}\text { Scenario II } \\
\%\end{array}$ & $\begin{array}{c}\text { SD } \\
\%\end{array}$ & $\begin{array}{c}\text { Scenario III } \\
\%\end{array}$ & $\begin{array}{c}\text { SD } \\
\%\end{array}$ \\
\hline Carbon dioxide $\left(\mathrm{CO}_{2}\right)$ & 8.19 & 0.45 & 11.09 & 3.83 & 23.31 & 1.29 \\
Oxygen $\left(\mathrm{O}_{2}\right)$ & 21.22 & 0.35 & 19.22 & 3.07 & 9.81 & 5.59 \\
Carbon monoxide $(\mathrm{CO})$ & 0.05 & 0.01 & 0.03 & 0.05 & 0.12 & 0.16 \\
\hline
\end{tabular}

SD: standard deviation 
(Tchobanoglous et al. 1994) and their presence has significant implications on health effects. However, from the socio-economic perspective of producers, the sawdust used in brick kilns as fuel is a low-cost available option.

The electrical power consumption for scenario II $(230 \mathrm{~W})$ and scenario III $(460 \mathrm{~W})$ was calculated according to each HB motor. The electricity LCI (Table II) was used in an LCA study previously published (López-Aguilar et al. 2016). In this study case, it was assumed that the regional characteristics of electricity production represent the impact of electricity consumption even when it supplies a national electrical network.

The Mexican clay fired-brick manufacturing LCI (Table III) contributes to the development of the national inventory database that represents local materials and processes. According to Guüreca et al. (2015) this is an important aspect to increase the use of LCA in Mexico.
TABLE II. LIFE CYCLE INVENTORY (LCI) OF ELECTRICITY GENERATION FROM EL ENCINO COMBINED-CYCLE POWER PLANT (660 MW)*

\begin{tabular}{lc}
\hline \multicolumn{2}{c}{ Outputs to the technosphere } \\
\hline Inventory category & LCI data \\
Electricity (MW) & 1.00 \\
Natural Gas (m ${ }^{3}$ ) & $2.15 \mathrm{E}-04$ \\
Carbon dioxide (ton) & $15.55 \mathrm{E}+04$ \\
Carbon monoxide (ton) & $1.16 \mathrm{E}+02$ \\
Methane (ton) & 12.16 \\
Nitrous oxide (ton) & 4.24 \\
Sulfur dioxide (ton) & 4.52 \\
Nitrogen oxides (ton) & $4.52 \mathrm{E}+02$ \\
Total suspended particles (TSP) (ton) & 9.33 \\
Total organic carbon ton/month (TOC) (ton) & 15.55 \\
Volatile organic compounds ton/month & \\
(VOC) (ton) & 7.62 \\
\hline
\end{tabular}

*Data collected from the power plant $\left(28^{\circ} 23^{\prime} 22.71^{\prime \prime} \mathrm{N}, 105^{\circ}\right.$ 55 ' 15.93" W) in May 2013, calculated with AP-42 parameters (EPA 2009).

TABLE III. LIFE CYCLE INVENTORY OF MEXICAN CLAY-FIRED BRICK MANUFACTURING

\begin{tabular}{|c|c|c|c|c|c|}
\hline Inventory category & Unit & Scenario I & Scenario II & Scenario III & Data collection methods \\
\hline \multicolumn{6}{|c|}{ Nature Inlet } \\
\hline Air & $\mathrm{kg}$ & 11.14 & 4.10 & 2.83 & $\begin{array}{l}\text { Mass balance calculation from measurements of } \mathrm{O}_{2} \\
\text { excess (gas analysis with Testo equipment) in April } \\
\text { 2014. Location: } 28^{\circ} 36^{\prime} 54.3^{\prime \prime} \mathrm{N}, 105^{\circ} 57^{\prime} 58.25^{\prime \prime} \mathrm{W}\end{array}$ \\
\hline \multicolumn{6}{|c|}{ Technosphere inlet } \\
\hline Water & liters & 0.2 & 0.2 & 0.2 & In situ measurements in January 2014. Location: $28^{\circ}$ \\
\hline Clay & $\mathrm{kg}$ & 1.29 & 1.29 & 1.29 & $36^{\prime} 54.3^{\prime \prime} \mathrm{N}, 105^{\circ} 57^{\prime} 58.25^{\prime} \mathrm{W}$ \\
\hline Sawdust & $\mathrm{kg}$ & 0.86 & 0.62 & 0.41 & \\
\hline $\begin{array}{l}\text { Water transportation } \\
\text { Clay transportation }\end{array}$ & $\begin{array}{l}\mathrm{km} \\
\mathrm{km}\end{array}$ & $\begin{array}{l}1.87 \\
18.95\end{array}$ & $\begin{array}{l}1.87 \\
18.95\end{array}$ & $\begin{array}{l}1.87 \\
18.95\end{array}$ & \multirow{2}{*}{$\begin{array}{l}\text { Information provided by producers and completed } \\
\text { with the ecoinvent database (diesel-powered trucks } \\
\text { from the US; Weidema et al. 2013) in January } 2014 \text {. } \\
\text { Location: } 28^{\circ} 36^{\prime} 54.3^{\prime \prime} \mathrm{N}, 105^{\circ} 57^{\prime} 58.25^{\prime \prime} \mathrm{W}\end{array}$} \\
\hline Sawdust transportation & $\mathrm{km}$ & 12.69 & 9.07 & 6.04 & \\
\hline Electricity & $\mathrm{kJ}$ & - & 0.58 & 1.16 & Table II \\
\hline \multicolumn{6}{|c|}{ Output } \\
\hline Bricks & piece & 1.00 & 1.00 & 1.00 & Information provided by the producers in February \\
\hline Firing time & hours & 16 & 12 & 8 & 201. Location: $28^{\circ} 36^{\prime} 54.3^{\prime \prime} \mathrm{N}, 105^{\circ} 57^{\prime} 58.25^{\prime \prime} \mathrm{W}$ \\
\hline \multicolumn{6}{|c|}{ Air emissions } \\
\hline $\mathrm{CO}_{2}$ & $\mathrm{~kg}$ & 1.29 & 0.92 & 0.62 & Gas analysis with Testo equipment in April 2013. \\
\hline $\mathrm{CO}$ & $\mathrm{kg}$ & $8.00 \mathrm{E}-03$ & $2.00 \mathrm{E}-03$ & $3.00 \mathrm{E}-03$ & Location: $28^{\circ} 36^{\prime} 54.3^{\prime \prime} \mathrm{N}, 105^{\circ} 57^{\prime} 58.25^{\prime \prime} \mathrm{W}$ \\
\hline Excess oxygen $\left(\mathrm{O}_{2}\right)$ & $\mathrm{kg}$ & 3.34 & 1.60 & 0.26 & \\
\hline Nitrogen inert from air & $\mathrm{kg}$ & 11.10 & 5.81 & 1.77 & Mass balance calculation based on information \\
\hline Dioxin polychlorinated & $\mathrm{kg}$ & 0.13 & 0.09 & 0.06 & provided by producers in April 2013. Location: $28^{\circ}$ \\
\hline $\mathrm{NO}_{\mathrm{x}}($ from fuel $)$ & $\mathrm{kg}$ & 0.06 & 0.04 & 0.03 & $36^{\prime} 54.3^{\prime \prime} \mathrm{N}, 105^{\circ} 57^{\prime} 58.25^{\prime} \mathrm{W}$ \\
\hline Water $\left(\mathrm{H}_{2} \mathrm{O}\right)$ & $\mathrm{kg}$ & 3.25 & 2.32 & 1.54 & \\
\hline
\end{tabular}




\section{Life cycle impact assessment (LCIA)}

The potential environmental impacts of the scenarios were evaluated under a life cycle framework using each of the methods and categories (Tables IV-VII).

TABLE IV. NOMENCLATURE OF IMPACT CATEGORIES FOR FIGURES 4-7

\begin{tabular}{lcl}
\hline Eco-indicator 99 & & \\
\hline Carcinogens & CA & DALY \\
Respiratory organics & RO & DALY \\
Respiratory inorganics & RI & DALY \\
Climate change & CC & DALY \\
Radiation & Ra & DALY \\
Ozone layer & OL & DALY \\
Ecotoxicity & ET & PDF $\cdot \mathrm{m}^{2} \cdot \mathrm{yr}$ \\
Acidification/eutrophication & $\mathrm{A} / \mathrm{E}$ & $\mathrm{PDF} \cdot \mathrm{m}^{2} \cdot \mathrm{y}$ \\
Land use & $\mathrm{LU}$ & $\mathrm{PDF} \cdot \mathrm{m}^{2} \cdot \mathrm{y}$ \\
Minerals & $\mathrm{Mi}$ & $\mathrm{MJ} \mathrm{surplus}$ \\
Fossil fuels & $\mathrm{FF}$ & $\mathrm{MJ}$ surplus \\
\hline
\end{tabular}

DALY: disability adjusted life years, PDF: potentially disappeared fraction, $\mathrm{MJ}$ : megajoules

TABLE V. NOMENCLATURE OF IMPACT CATEGORIES FOR FIGURE 4

\begin{tabular}{|c|c|c|}
\hline \multicolumn{3}{|c|}{ IMPACT 2002+ } \\
\hline Carcinogens & $\mathrm{CA}$ & $\mathrm{kg} \mathrm{C}_{2} \mathrm{H}_{3} \mathrm{Cl}$ eq \\
\hline Non-carcinogens & $\mathrm{N}-\mathrm{CA}$ & $\mathrm{kg} \mathrm{C}_{2} \mathrm{H}_{3} \mathrm{Cl}$ eq \\
\hline Respiratory inorganics & RI & $\mathrm{kg} \mathrm{PM}_{2.5}$ eq \\
\hline Ionizing radiation & IR & $\mathrm{Bq} \mathrm{C}-14 \mathrm{eq}$ \\
\hline Ozone layer depletion & OLD & kg CFC-11 eq \\
\hline Respiratory organics & RO & $\mathrm{kg} \mathrm{C} 2 \mathrm{H} 4 \mathrm{eq}$ \\
\hline Aquatic ecotoxicity & AE-Tox & kg TEG water \\
\hline Terrestrial ecotoxicity & $\mathrm{TE}$ & kg TEG soil \\
\hline $\begin{array}{l}\text { Terrestrial acidification/ } \\
\text { nutrification }\end{array}$ & $\mathrm{T}-\mathrm{A} / \mathrm{N}$ & $\mathrm{kg} \mathrm{SO}_{2} \mathrm{eq}$ \\
\hline Land occupation & LO & $\mathrm{m}^{2}$ org.arable \\
\hline Aquatic acidification & $\mathrm{AA}$ & $\mathrm{kg} \mathrm{SO} 2 \mathrm{eq}$ \\
\hline Aquatic eutrophication & $\mathrm{AE}$ & $\mathrm{kg} \mathrm{PO}_{4} \mathrm{P}-\mathrm{lim}$ \\
\hline Global warming & GW & $\mathrm{kg} \mathrm{CO}_{2}$ eq \\
\hline Non-renewable energy & N-RE & MJ primary \\
\hline Mineral extraction & MEx & MJ surplus \\
\hline
\end{tabular}

Eq: equivalent, PM: particulate matter, CFC-11: trichlorofluoromethane, TEG water: triethylene glycol into water, TEG soil: triethylene glycol into soil.

\section{INTERPRETATION}

LCA studies could present the limitations of their application in different countries, with the exception of the resources damaged and the damage created by
TABLE VI. NOMENCLATURE OF IMPACT CATEGORIES FOR FIGURE 5

\begin{tabular}{|c|c|c|}
\hline \multicolumn{3}{|c|}{ CML 2001} \\
\hline Acidification & $\mathrm{AC}$ & $\mathrm{kg} \mathrm{SO}_{2}$ eq \\
\hline Eutrophication & EU & $\mathrm{kg} \mathrm{PO}_{4} \mathrm{eq}$ \\
\hline Global warming 20a & GW-20 & $\mathrm{kgCO}_{2} \mathrm{eq}$ \\
\hline $\begin{array}{l}\text { Upper limit of net global } \\
\text { warming }\end{array}$ & ULGW & $\mathrm{kg} \mathrm{CO} 2$ eq \\
\hline $\begin{array}{l}\text { Lower limit of net global } \\
\text { warming }\end{array}$ & LLGW & $\mathrm{kg} \mathrm{CO}_{2}$ eq \\
\hline Ozone layer depletion 10a & OLD-10 & $\mathrm{kg} \mathrm{CFC}-11 \mathrm{eq}$ \\
\hline Ozone layer depletion 20a & OLD-20 & $\mathrm{kg} \mathrm{CFC}-11 \mathrm{eq}$ \\
\hline $\begin{array}{l}\text { Ozone layer depletion steady } \\
\text { state }\end{array}$ & OLD-SS & kg CFC-11 eq \\
\hline Human toxicity $20 \mathrm{a}$ & HT-20 & kg 1,4-DB eq \\
\hline Human toxicity infinite & HT-IN & kg $1,4-\mathrm{DB}$ eq \\
\hline Freshwater aquatic ecotoxicity & & \\
\hline $20 \mathrm{a}$ & FAE-20 & $\mathrm{kg} \mathrm{1,4-DB} \mathrm{eq}$ \\
\hline Marine aquatic ecotoxicity $20 \mathrm{a}$ & MAE-20 & kg $1,4-\mathrm{DB}$ eq \\
\hline $\begin{array}{l}\text { Marine aquatic ecotoxicity } \\
\text { infinite }\end{array}$ & MAE-Inf & $\mathrm{kg} 1,4-\mathrm{DB}$ eq \\
\hline Terrestrial ecotoxicity 20a & TE-20 & $\mathrm{kg} 1,4-\mathrm{DB}$ eq \\
\hline Terrestrial ecotoxicity infinite & TE-Inf & $\mathrm{kg} 1,4-\mathrm{DB}$ eq \\
\hline Marine sediment ecotoxicity $20 \mathrm{a}$ & MSE-20 & $\mathrm{kg} 1,4-\mathrm{DB}$ eq \\
\hline $\begin{array}{l}\text { Marine sediment ecotoxicity } \\
\text { infinite }\end{array}$ & MSE-Inf & $\mathrm{kg} \mathrm{1,4-DB} \mathrm{eq}$ \\
\hline Freshwater sediment ecotoxicity & & \\
\hline $20 \mathrm{a}$ & FSE-20 & $\mathrm{kg} 1,4-\mathrm{DB}$ eq \\
\hline $\begin{array}{l}\text { Freshwater sediment ecotoxicity } \\
\text { infinite }\end{array}$ & FSE-Inf & kg 1,4-DB eq \\
\hline Average European (kg NOx eq) & AE-NOx & $\mathrm{kg} \mathrm{NO}$ eq \\
\hline Average European (kg SO2-Eq) & AE-SOx & $\mathrm{kg} \mathrm{SO}_{2} \mathrm{eq}$ \\
\hline Land competition & $\mathrm{LC}$ & $\mathrm{m}^{2}$ area \\
\hline Ionising radiation & IR & DALY \\
\hline Photochemical oxidation & $\mathrm{PhO}$ & $\mathrm{kg} \mathrm{C}_{2} \mathrm{H}_{4} \mathrm{eq}$ \\
\hline Photochemical oxidation (low & & \\
\hline NOx) & PhO_INOx & $\mathrm{kg} \mathrm{C}_{2} \mathrm{H}_{4}$ eq \\
\hline Malodours air & $\mathrm{MA}^{-}$ & $\mathrm{m}^{3}$ air \\
\hline $\begin{array}{l}\text { Equal benefit incremental } \\
\text { reactivity }\end{array}$ & EBIR & $\mathrm{kg}$ formed $\mathrm{O}_{3}$ \\
\hline Maximum incremental reactivity & MaxIR & $\mathrm{kg}$ formed $\mathrm{O}_{3}$ \\
\hline $\begin{array}{l}\text { Maximum ozone incremental } \\
\text { reactivity }\end{array}$ & MaxOIR & $\mathrm{kg}$ formed $\mathrm{O}_{3}$ \\
\hline
\end{tabular}

CFC-11: trichlorofluoromethane, 1,4-DB: 1,4-dichlorobenzene, DALY: disability adjusted life years

climate change, ozone layer depletion, air emissions of persistent carcinogenic substances and inorganic air pollutants with long-range dispersion. Lopsik (2013) concluded that the limitations and the assumptions made during the LCA study should be taken into account for interpreting impact assessment results.

Also, when using LCA, it is important to make a conscious choice of the database and LCIA methods to be used, knowing the consequences of decisions made in the study (Zhang et al. 2013). According to 
TABLE VII. NOMENCLATURE OF IMPACT CATEGORIES FOR FIGURE 6

\begin{tabular}{|c|c|c|}
\hline \multicolumn{3}{|c|}{ ReCiPe midpoint } \\
\hline Climate change & $\mathrm{CC}$ & $\mathrm{kg} \mathrm{CO} 2 \mathrm{eq}$ \\
\hline Ozone depletion & OD & $\mathrm{kg} \mathrm{CFC}-11 \mathrm{eq}$ \\
\hline Terrestrial acidification & TA & $\mathrm{kg} \mathrm{SO}_{2} \mathrm{eq}$ \\
\hline Freshwater eutrophication & $\mathrm{FE}$ & $\mathrm{kg} \mathrm{P} \mathrm{eq}$ \\
\hline Marine eutrophication & Meu & $\mathrm{kg} \mathrm{N} \mathrm{eq}$ \\
\hline Human toxicity & HT & $\mathrm{kg} 1,4-\mathrm{DB}$ eq \\
\hline Photochemical oxidant formation & POF & kg NMVOC \\
\hline Particulate matter formation & PMF & $\mathrm{kg} \mathrm{PM}_{10} \mathrm{eq}$ \\
\hline Terrestrial ecotoxicity & TE & $\mathrm{kg} 1,4-\mathrm{DB}$ eq \\
\hline Freshwater ecotoxicity & FE-Tox & $\mathrm{kg} \mathrm{1,4-DB} \mathrm{eq}$ \\
\hline Marine ecotoxicity & $\mathrm{MEc}$ & $\mathrm{kg} \mathrm{1,4-DB} \mathrm{eq}$ \\
\hline Ionising radiation & IR & $\mathrm{kg} \mathrm{U}^{235} \mathrm{eq}$ \\
\hline Agricultural land occupation & ALO & $\mathrm{m}^{2}$ area \\
\hline Urban land occupation & ULO & $\mathrm{m}^{2}$ area \\
\hline Natural land transformation & NLT & $\mathrm{m}^{2}$ \\
\hline Water depletion & WD & $\mathrm{m}^{3}$ \\
\hline Metal depletion & MD & $\mathrm{kg} \mathrm{Fe} \mathrm{eq}$ \\
\hline Fossil depletion & FD & $\mathrm{kg}$ oil eq \\
\hline
\end{tabular}

CFC-11: trichlorofluoromethane, 1,4-DB: 1,4-dichlorobenzene, NMVOC: non-methane volatile organic compounds, PM: particulate matter

Rørbech et al. (2014), the selection of a method in specific LCAs may significantly affect its results and comparability with other studies. Thus, a sensitivity analysis was carried out based on comparing the variation of results using the LCIA methods. The analyses of the three scenarios are discussed below.

Eco-indicator 99 . The results are shown in figure 3, where a substantial decrease is observed (scenarios IIII) in impact categories like carcinogens, respiratory inorganic, ecotoxicity acidification/eutrophication and climate change. This last category is influenced by GHG emissions. Otherwise, the categories radiation, ozone layer, minerals and fossil fuels show an increase of less than $6.5 \%$ caused by electricity consumption. The land use category remained constant regardless of the presence of the HB device.

Impact 2002+. Figure 4 shows a decrease through scenarios II and III in the categories carcinogens, no carcinogens, respiratory inorganics, aquatic and terrestrial ecotoxicity, terrestrial and aquatic acidification as well as global warming, which includes GHG emissions. The ionizing radiation, ozone layer depletion and respiratory organics categories present a slight increase of $\sim 3 \%$, attributed to the addition of HB devices. On the other hand, there is an increase of $\sim 46 \%$ in the score of scenario II comparing to scenario I, whereas scenario III is $\sim 63 \%$ higher tan scenario I. This slight recovery percentage is attributed to the electricity demand characteristic of the fuel consumption (natural gas) of the combined cycle plant under study.

CML 2001. Both CML 2001 and the ReCiPe methods (Figs. 5 and $\mathbf{6}$ ) consider the emissions in a

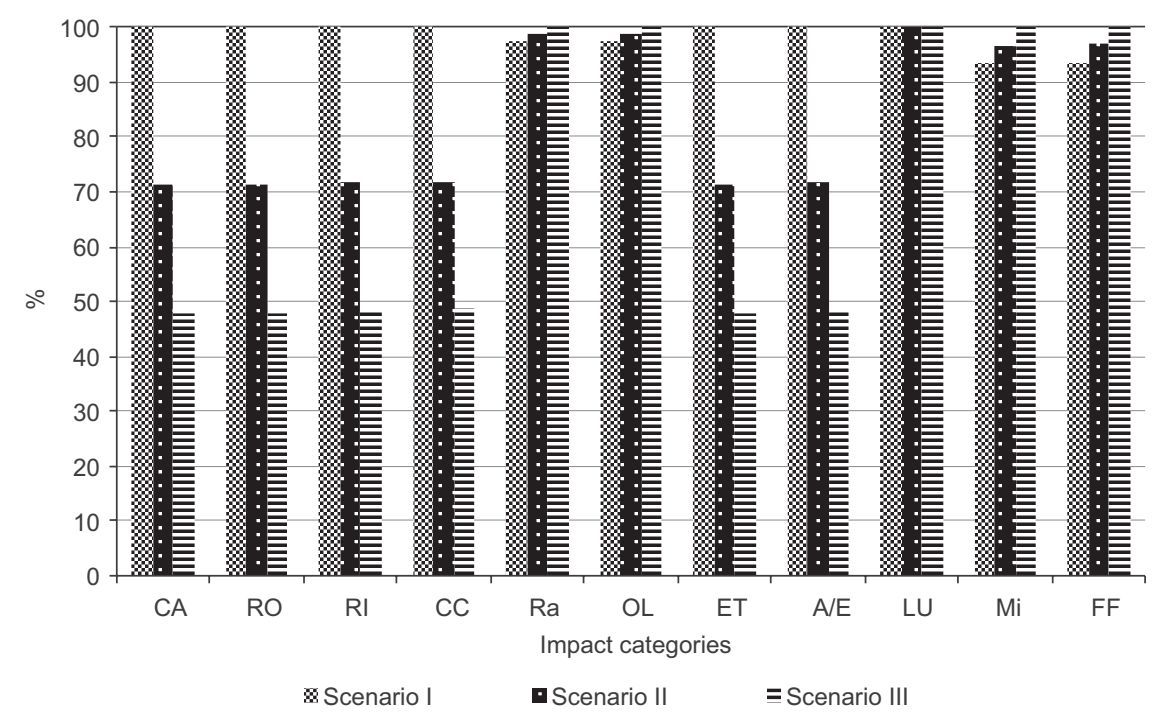

Fig. 3. Average contributions of life cycle impact assessment using Eco-indicator 99 damage approach for scenario I (traditional manufacturing), scenario II (one hopper-blower) and scenario III (two hopper-blowers). CA: carcinogens, RO: respiratory organics, $\mathrm{RI}$ : respiratory inorganics, CC: climate change, Ra: radiation, OL: ozone layer, ET: ecotoxicity, A/E: acidification/eutrophication, LU: land use, Mi: minerals, FF: fossil fuels (nomenclature in table IV) 


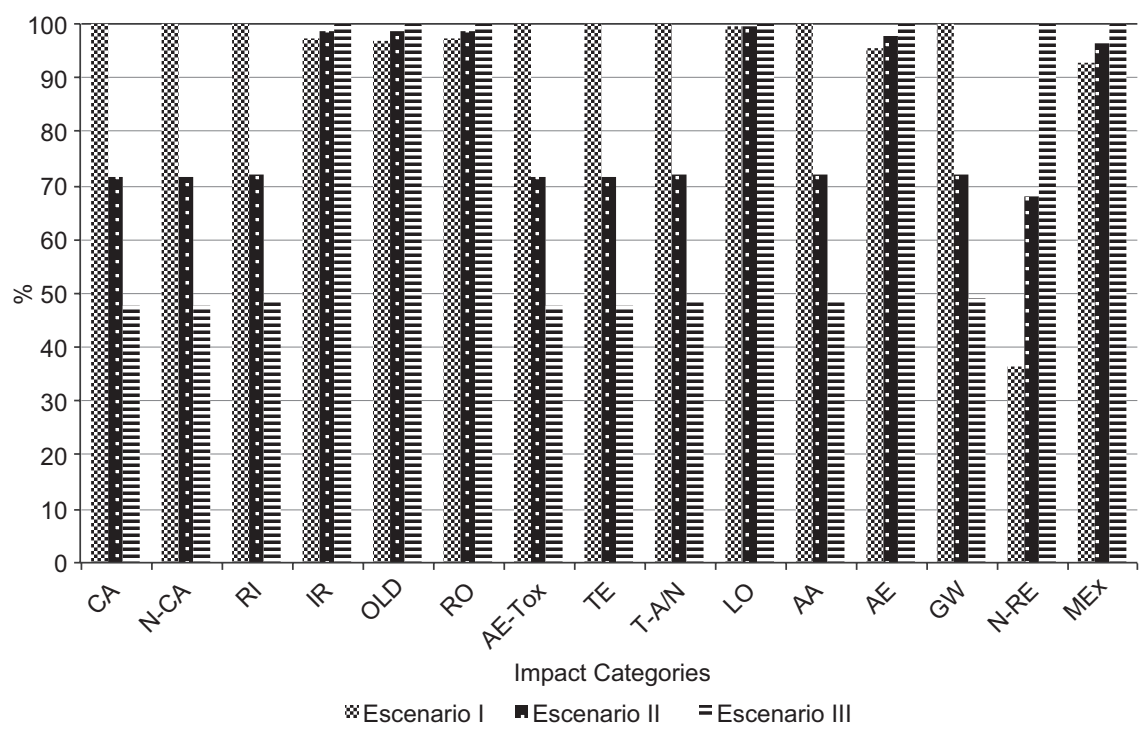

Fig. 4. Average contributions of life cycle impact assessment using IMPACT 2002 midpoint damage approach for scenario I (traditional manufacturing), scenario II (one hopper-blower) and scenario III (two hopper-blowers). CA: carcinogens, N-CA: non-carcinogens, RI: respiratory inorganics, IR: ionizing radiation, OLD: ozone layer depletion, RO: respiratory organics, AE-Tox: aquatic ecotoxicity, TE: terrestrial ecotoxicity, T-A/N: terrestrial acidification/nutrification, LO: land occupation, AA: aquatic acidification, $\mathrm{AE}$ : aquatic eutrophication, GW: global warming, N-RE: nonrenewable energy, Mex: mineral extraction (nomenclature in table V)

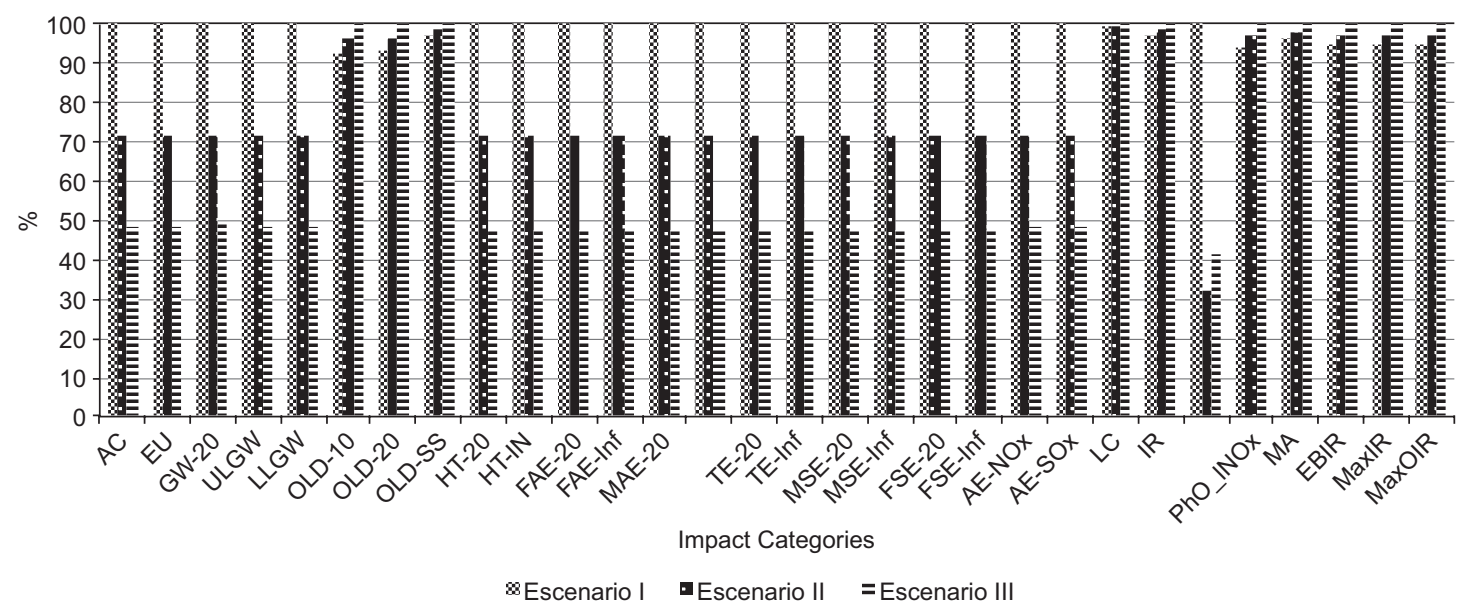

Fig. 5. Average contributions of life cycle impact assessment using CML 2001 midpoint approach for scenario I (traditional manufacturing), scenario II (one hopper-blower) and scenario III (two hopper-blower). AC: acidification, EU: eutrophication, GW-20: global warming 20 years, ULGW: upper limit of net global warming, LLGW: lower limit of net global warming, OLD-10: ozone layer depletion 10 years, OLD-20: ozone layer depletion 20 years, OLD-SS: ozone layer depletion steady state, HT-20: human toxicity 20 years, HT-IN: human toxicity infinite, FAE-20: freshwater aquatic ecotoxicity 20 years, MAE-20: marine aquatic ecotoxicity 20 years, MAE-Inf: marine aquatic ecotoxicity infinite, TE-20: terrestrial ecotoxicity 20 years, TE-Inf: terrestrial ecotoxicity infinite, MSE-20: marine sediment ecotoxicity 20 years, MSE-Inf: marine sediment ecotoxicity infinite, FSE-20: freshwater sediment ecotoxicity 20 years, FSE-Inf: freshwater sediment ecotoxicity infinite, AE-NOx: average European ( $\left.\mathrm{kg} \mathrm{NO}_{\mathrm{x}} \mathrm{eq}\right), \mathrm{AE}-\mathrm{SOx}$ : average European $\left(\mathrm{kg} \mathrm{SO}_{2} \mathrm{Eq}\right), \mathrm{LC}$ : land competition, IR: ionizing radiation, PhO: photochemical oxidation, PhO_INOx: photochemical oxidation (low $\mathrm{NO}_{\mathrm{x}}$ ), MA: malodorous air, EBIR: equal benefit incremental reactivity, MaxIR: maximum incremental reactivity, MaxOIR: maximum ozone incremental reactivity (nomenclature in table VI) 


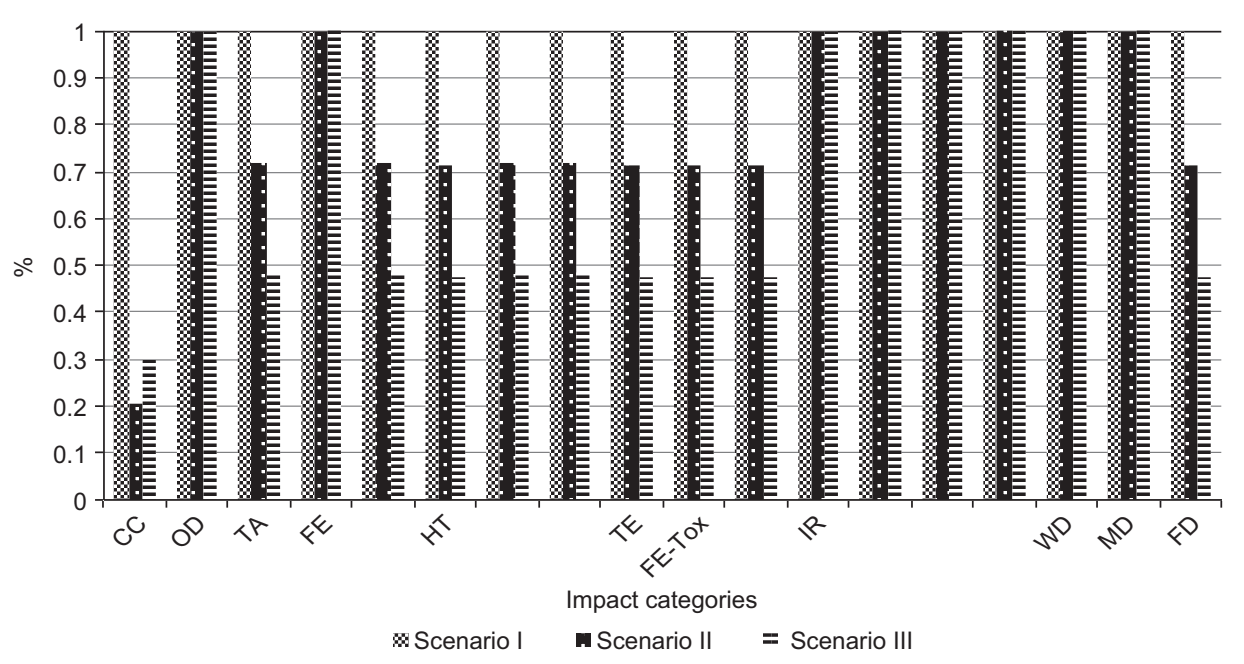

Fig. 6. Average contributions of life cycle impact assessment using ReCiPe midpoint approach for scenario I (traditional manufacturing), scenario II (one hopper-blower) and scenario III (two hopper-blower). CC: climate change, OD: ozone depletion, TA: terrestrial acidification, FE: freshwater eutrophication, Meu: marine eutrophication, HT: human toxicity, POF: photochemical oxidant formation, PMF: particulate matter formation, TE: terrestrial ecotoxicity, FE-Tox: freshwater ecotoxicity, MEc: marine ecotoxicity, IR: ionizing radiation, ALO: agricultural land occupation, ULO: urban land occupation (nomenclature in table VII)

greater number of categories and at different periods of time (10 and $20 \mathrm{yrs})$. In this method, a decrease in impact categories of $\sim 50 \%$ (scenarios I-III) is observed in the categories acidification, eutrophication, global warming (all of the time lapses presented), human toxicity, fresh water aquatic ecotoxicity (all of the time lapses), marine ecotoxicity infinite, terrestrial ecotoxicity (20a and infinity), marine sediment ecotoxicity (20a and infinity), fresh water sediment ecotoxicity (20a and infinity), and average European $\left(\mathrm{kg}\right.$ of $\mathrm{NO}_{\mathrm{x}}$ and $\mathrm{SO}_{\mathrm{x}}$ ). An increase greater than $8 \%$ in Ozone layer depletion (for 10a, 20a and steady state), ionizing radiation, photochemical oxidation, malodorous air, equal benefit incremental reactivity, maximal incremental reactivity and maximal ozone incremental reactivity categories, can be seen in figure 5. The categories related to ozone layer depletion remain constant trough the scenarios. In the photochemical oxidation category, a substantial decrease was observed between scenarios I and II; however, comparing scenarios II and III, a moderate increase was detected. The behavior in the photochemical oxidation midpoint category is due to carbon monoxide emissions. Scenario III has a higher percentage of carbon monoxide emissions than scenario II.

$R e C i P e$. In figure 6, a significant reduction of over $50 \%$ (scenarios I-III) is observed in terrestrial acidification, marine eutrophication, human toxicity, photochemical oxidant formation, particulate matter formation, terrestrial ecotoxicity, fresh water ecotoxicity, marine ecotoxicity, and fossil depletion. The other categories remain practically constant. The climate change category decreases $74 \%$ when comparing scenarios I and II, while the comparison between scenario II and III shows an increase of $7 \%$, which is caused by the use of two HB. The $\mathrm{ReCiPe}$ method does not consider the $\mathrm{CO}$ gas in its GHG analysis, although this contributes indirectly to the greenhouse effect and also indicates incomplete combustion.

Each LCA database is developed by an organism in a specific location, and the modeled processes are based on its manufacturing characteristics (MartínezRocamora et al. 2016). Even when ecoinvent was developed by the Swiss Centre for Life Cycle Inventories, the present study complements this database by including more adequate inventories for Mexico.

A significantly decreasing trend was observed in most of the potential impact categories analyzed using the selected methods. The lower level of emissions arises from the inclusion of one HB device due to the improvement of the manufacturing process efficiency in firing time (Table III). According to Kumbhar et al. (2014) the highly energy-intensive process of traditional brick production needs an efficient fuel burning method to reduce the environmental impact of the production process. Additionally, it was observed that a prolonged firing time had no significant effect on the mechanical and physical properties of bricks. 
In order to validate this work, table VIII shows a comparison of traditional brick kiln technology (sawdust as fuel) and tunnel brick technology (pet coke as fuel) applied in Greece (Koroneos and Dompros 2007). Even though biomass (sawdust) is supposed to be a cleaner fuel than pet coke, both studies show similar $\mathrm{CO}_{2}$ emissions. Moreover, any of the reviewed LCA studies consider the category of carcinogens (or impacts related to polychlorinated emissions) in their impact analysis (Khan et al. 2007, Cappuyns and Kessen 2012, Quirós et al. 2015). Table IX shows a comparison of the carcinogens and ecotoxicity categories of the present study with an LCA of traditional soil brick carried out on 16 traditional brick kilns located in India (Kumbhar et al. 2014).

TABLE VIII. COMPARISON OF $\mathrm{CO}_{2}$ EMITTED BY TRADITIONAL BRICK KILNS (MEXICO) AND TUNNEL BRICK KILNS (GREECE)

\begin{tabular}{lcc}
\hline Scenario location & Chihuahua, Mexico & Tessaloniki, Greek \\
\hline $\begin{array}{l}\text { Technology } \\
\text { Capacity } \\
\text { (bricks per year) }\end{array}$ & Traditional brick kiln & Tunnel brick kiln \\
$\begin{array}{l}\text { Fuel type } \\
\text { kg-CO } 2 \text { equivalent } \\
\text { per brick }\end{array}$ & Sawdust & $1.24 \mathrm{E}+06$ \\
\hline
\end{tabular}

In this study case, the $\mathrm{GHG}$ emissions in $\mathrm{CO}_{2}$ equivalents were calculated from the energy inputs of the various processes in the LCI and they were used as an indicator of energy use. The LCA results identified an improvement opportunity for the energy efficiency of the process by using one HB device in the clamp kiln.

It has been verified that the obtained information is relevant and reliable for the environmental impact comparison, since testing different assessment methods helps to determine the influence on data variations and the sensitivity of processes (Lopsik 2013).

\section{CONCLUSIONS}

This study assessed the environmental impacts of three clamp kiln scenarios applying an LCA. It is a contribution to the application of LCA to the environmental assessment and the improvement of traditional processes in Mexico, where the evolution of LCA has been slower than in developed countries.

The LCIA results previously discussed were found to be quite sensitive to changes in GHG emissions, which were used as an indicator of energy consumption. An improved environmental performance was achieved when one device was used, as evidenced by the decrease in emissions.

It was observed that there are residual impacts that increase by adding blowers, such as radiation, eutrophication or depletion of the ozone layer. This study identifies the importance of the life-cycle impacts by improving the environmental performance of traditional technologies, especially in countries

TABLE IX. COMPARISON OF THE CATEGORIES RELATED TO POTENTIAL POLYCHLORINATED EMISSIONS

\begin{tabular}{|c|c|c|c|}
\hline \multirow[t]{2}{*}{ Technology } & \multirow[t]{2}{*}{ Unit } & Chihuahua, México & Maharashtra, India \\
\hline & & $\begin{array}{l}\text { Traditional brick kiln } \\
\text { coal combustion }\end{array}$ & $\begin{array}{l}\text { Traditional brick kiln sawdust } \\
\text { combustion }\end{array}$ \\
\hline Functional unit & bricks & \multicolumn{2}{|c|}{1000 units } \\
\hline Carcinogens & \multirow{10}{*}{$\mathrm{Pt}$} & $6.57 \mathrm{E}+08$ & $4.65 \mathrm{E}-08$ \\
\hline Respiratory organics & & 7.70 & $4.13 \mathrm{E}-09$ \\
\hline Respiratory inorganics & & 155.37 & $9.18 \mathrm{E}-05$ \\
\hline Climate change & & 7.52 & $4.45 \mathrm{E}-06$ \\
\hline Radiation & & $4.28 \mathrm{E}-06$ & $7.11 \mathrm{E}-11$ \\
\hline Ozone layer & & $2.40 \mathrm{E}-07$ & $2.84 \mathrm{E}-11$ \\
\hline Ecotoxicity & & $1.25 \mathrm{E}+06$ & $7.74 \mathrm{E}-10$ \\
\hline Acidification/eutrophication & & 25.20 & $2.67 \mathrm{E}-06$ \\
\hline Land use & & $-2.77 \mathrm{E}-02$ & $-1.80 \mathrm{E}-06$ \\
\hline Minerals & & $6.68 \mathrm{E}-06$ & $7.57 \mathrm{E}-07$ \\
\hline
\end{tabular}

Pt: points of life cycle assessment 
where economic and social aspects do not allow the complete replacement or technological upgrade of these processes.

Future studies are recommended to analyze particle and $\mathrm{NO}_{\mathrm{x}}$ emissions using the $\mathrm{HB}$ device during the production stage, even though the firing time decreased.

The inventory information contributes to the development of the national life-cycle inventory (LCI) database and it could be applicable to others countries where the manufacturing process is similar.

\section{ACKNOWLEDGMENTS}

This study was supported and funded by Centro de Investigación en Materiales Avanzados S. C., Universidad Autónoma de Chihuahua, Universidad Autónoma de Ciudad Juárez. The authors would like to thank M. Sc. Elías Ramirez Espinoza as well as the "Secretaría de Energía" and the "Consejo Nacional de Ciencia y Tecnología" (project SENER-CONACyT No243715).

\section{REFERENCES}

Agrawal K.K., Jain S., Jain A.K. and Dahiya S. (2014). Assessment of greenhouse gas emissions from coal and natural gas thermal power plants using life cycle approach. Int. J. Environ. Sci. Tech. 11 (4), 1157-1164. DOI: $10.1007 / \mathrm{s} 13762-013-0420-\mathrm{z}$

Bare J.C. and Gloria T.P. (2006). Critical analysis of the mathematical relationships and comprehensiveness of life cycle impact assessment approaches. Environ. Sci. Technol. 40 (4), 1104-1113.

DOI: $10.1021 / \mathrm{es} 051639$

Bovea M. D., Cruz-Sotelo S. E., Mercante I., CoutinhoNóbrega C., Eljaiek-Ursola M. and Ibáñez-Flores V. (2017). Aplicación de la metodología de Análisis de Ciclo de Vida para evaluar el desempeño ambiental de sistemas de gestión de residuos en Iberoamerica. Rev. Int. Contam. Ambie. 32 (especial residuos sólidos), 23-46. DOI: 10.20937/RICA.2016.32.05.03

Bribián I.Z., Uson A.A. and Scarpellini S. (2009). Life cycle assessment in buildings: State-of-the-art and simplified LCA methodology as a complement for building certification. Build. Environ. 44 (12), 25102520. DOI: 10.1016/j.buildenv.2009.05.001

Buyle M., Braet J. and Audenaert A. (2013). Life cycle assessment in the construction sector: A review. Renew. Sust. Energ. Rev. 26, 379-388.

DOI: 10.1016/j.rser.2013.05.001
Cappuyns V. and Kessen B. (2012). Evaluation of the environmental impact of Brownfield remediation options: Comparison of two life cycle assessment-based evaluation tools. Environ. Technol. 33 (21), 2447-2459. DOI: 10.1080/09593330.2012.671854

Castell A., Menoufi K., de Gracia A., Rincón L., Boer D. and Cabeza L.F. (2013). Life cycle assessment of alveolar brick construction system incorporating phase change materials (PCMs). Appl. Energ. 101, 600-608. DOI: 10.1016/j.apenergy.2012.06.066

EPA (1995). Stationary internal combustion sources. En: AP-42 Compilation of air pollutant emission factors. Vol. 1, 5a ed. Office of Air Quality Plannig and Standards, Office of Air and Radiation, Environmental Protection Agency, Washington, D.C. EUA.

Güereca L.P., Sosa R.O., Gilbert H.E. and Reynaga N S. (2015). Life cycle assessment in Mexico: Overview of development and implementation. Int. J. Life Cycle Assess. 20 (3), 311-317. DOI: 10.1007/s11367-014-0844-9

Hoxha E., Habert G., Lasvaux S., Chevalier J. and Le Roy R. (2017). Influence of construction material uncertainties on residential building LCA reliability. J. Clean. Prod. 144, 33-47. DOI: 10.1016/j.jclepro.2016.12.068

Ibbotson S. and Kara S. (2013). LCA case study. Part 1: cradle-to-grave environmental footprint analysis of composites and stainless steel I-beams. Int. J. Life Cycle Ass. 18 (1), 208-217.

DOI: $10.1007 / \mathrm{s} 11367-012-0452-5$

INECC (2013). Apoyo a la iniciativa de planificación nacional sobre contaminantes climáticos de vida corta en México. Informe final. Instituto Nacional de Ecología y Cambio Climático, México, 77 pp. [en línea]. https://www.gob.mx/cms/uploads/attachment/ file/40813/2013_snap_mexico_esp.pdf

ISO (2006a). ISO 14040. Environmental management-Life cycle assessment-Principles and framework. International Organization for Standardization, Geneva.

ISO (2006b). ISO 14044. Environmental managementLife cycle assessment-Requirements and guidelines. International Organization for Standardization, Geneva.

Khan H.R., Rahman K., Rouf A.A., Sattar G.S., Oki Y. and Adachi T. (2007). Assessment of degradation of agricultural soils arising from brick burning in selected soil profiles. Int. J. Environ. Sci. Tech. 4 (4), 471-480. DOI: $10.1007 / \mathrm{BF} 03325983$

Koroneos C. and Dompros A. (2007). Environmental assessment of brick production in Greece. Build. Environ. 42 (5), 2114-2123. DOI: 10.1016/j.buildenv.2006.03.006

Kumbhar S., Kulkarni N., Rao A.B. and Rao B. (2014). Environmental life cycle assessment of traditional bricks in western Maharashtra, India. Energy Procedia. 54, 260-269. DOI: 10.1016/j.egypro.2014.07.269 
Lasvaux S., Habert G., Peuportier B. and Chevalier J. (2015). Comparison of generic and product-specific life cycle assessment databases: Application to construction materials used in building LCA studies. Int. J. Life Cycle Ass. 20 (11), 1473-1490. DOI: $10.1007 / \mathrm{s} 11367-015-0938-\mathrm{z}$

López-Aguilar H.A., Huerta-Reynoso E.A., Gómez J.A., Olivarez-Ramírez J.M., Duarte-Moller A. and PérezHernández A. (2016). Life cycle assessment of regional brick manufacture. Mater. Constr. 66 (322), 085. DOI: $10.3989 / \mathrm{mc} .2016 .02315$

Lopsik K. (2013). Life cycle assessment of small-scale constructed wetland and extended aeration activated sludge wastewater treatment system. Int. J. Environ. Sci. Tech. 10 (6), 1295-1308. DOI: $10.1007 / \mathrm{s} 13762-012-0159-\mathrm{y}$

Martínez-Rocamora A., Solís-Guzmán J. and Marrero M. (2016). LCA databases focused on construction materials: A review. Renew. Sust. Energ. Rev.58, 565-573. DOI: $10.1016 /$ j.rser.2015.12.243

Nouri J., Nouri N. and Moeeni M. (2012). Development of industrial waste disposal scenarios using life-cycle assessment approach. Int. J. Environ. Sci. Tech. 9 (3), 417-424. DOI: 10.1007/s13762-012-0076-0

Quirós R., Villalba G., Gabarrel X. and Muñoz P. (2015). Life cycle assessment of organic and mineral fertilizers in a crop sequence of cauliflower and tomato. Int. J. Environ. Sci. Tech. 12 (10), 1-18. DOI: $10.1007 / \mathrm{s} 13762-015-0756-7$

Rajarathnam U., Athalye V., Ragavan S., Maithel S., Lalchandani D., Kumar S. and Bond T. (2014). Assessment of air pollutant emissions from brick kilns. Atmos. Environ. 98, 549-553. DOI: $10.1016 /$ j.atmosenv.2014.08.075

Rørbech J.T., Vadenbo C., Hellweg S. and Astrup T.F. (2014). Impact assessment of abiotic resources in LCA: Quantitative comparison of selected characterization models. Environ. Sci. Technol. 48 (19), 11072-11081. DOI: $10.1021 /$ es5023976
Saner D., Heeren N., Jäggi B., Waraich R.A. and Hellweg S. (2013). Housing and mobility demands of individual households and their life cycle assessment. Environ. Sci. Technol. 47 (11), 5988-5997.

DOI: $10.1021 / \mathrm{es} 304084 \mathrm{p}$

Schmidt C.W. (2013). Modernizing artisanal brick kilns: A global need. Environ. Health Persp. 121 (8), A242249. DOI: $10.1289 /$ ehp.121-a242

Singh A.L. and Asgher M.S. (2005). Impact of brick kilns on land use/landcover changes around Aligarh city, India. Habitat. Int. 29 (3), 591-602.

DOI: 10.1016/j.habitatint.2004.04.010

Skinder B.M., Sheikh A.Q., Pandit A.K. and Ganai B.A. (2014). Brick kiln emissions and its environmental impact: A Review. J. Ecol. Nat. Environ. 6 (1), 1-11. DOI: 10.5897/JENE2013.0423

Tchobanoglous G., Theisen H. and Vigil S. (1994). Gestión integral de residuos sólidos. McGraw-Hill, México, $607 \mathrm{pp}$.

Tondeur Y., Nestrick T., Silva H.A., Vining B. and Hart J. (2010). Analytical procedures for the determination of polychlorinated-p-dioxins, polychlorinated dibenzofurans, and hexachlorobenzene in pentachlorophenol. Chemosphere 80 (2), 157-164.

DOI: 10.1016/j.chemosphere.2010.04.001

Weidema B.P., Bauer Ch., Hischier R., Mutel Ch., Nemecek T., Reinhard J., Vadenbo C.O. and Wernet G. (2013). Overview and methodology. Data quality guideline for the ecoinvent database version 3 . Ecoinvent Organization, Zurich [online]. https:// www.ecoinvent.org/files/dataqualityguideline_ecoinvent_3_20130506.pdf 15/10/2017

Zhang X., Shen L. and Zhang L. (2013). Life cycle assessment of the air emissions during building construction process: A case study in Hong Kong. Renew. Sust. Energ. Rev. 17, 160-169.

DOI: 10.1016/j.rser.2012.09.024 